Citation: Musin, G. E., BadilloZapata, D., Vega-Villasante, F.

Chong-Carrillo, O., \& Palma-Cancino, D. J. (2022). Survival of the prawn Macrobrachium tenellum (Smith, 1871) in confinement with the native fish Dormitator latifrons (Richardson, 1844). Agro Productividad. https://doi. org/10.32854/agrop.v15il.2088

Editor in Chief: Dr. Jorge Cadena Iñiguez

Received: July 14, 2021.

Accepted: December 12, 2021.

Published on-line: January, 2022.

This work is licensed under a Creative Commons Attribution-NonCommercial 4.0 International license.

\section{Survival of the prawn Macrobrachium tenellum (Smith, 1871) in confinement with the native fish Dormitator latifrons (Richardson, 1844)}

\author{
Musin, Gabriela E. ${ }^{\text {; }}$ Badillo-Zapata, Daniel ${ }^{2,3}$; Vega-Villasante, Fernando ${ }^{2}$; \\ Chong-Garrillo, Olimpia ${ }^{2}$; Palma-Cancino, David J. ${ }^{{ }^{*}}$ \\ 1 Instituto Nacional de Limnología. Consejo Nacional de Investigaciones Científicas y Técnicas (CONICET) \\ - Universidad Nacional del Litoral, Santa Fe, Argentina. \\ ${ }^{2}$ Universidad de Guadalajara. Centro Universitario de la Costa, Puerto Vallarta, Jalisco, México. G.P. 48220. \\ 3 Programa de Cátedras CONACYT. Consejo Nacional de Ciencia y Tecnología, Ciudad de México, México. \\ * Correspondence: plusdpc@gmail.com
}

\begin{abstract}
Objective: The aim of this study was to test the survival of Macrobrachium tenellum in different confinement conditions with Dormitator latifrons.

Design/methodology/approach: Using wild specimens acclimated to captive conditions of both species, three trials of different proportion were performed with treatments consisting in the presence/absence of food and shelters. Prawn/fish proportion for the assays were: 15/15 for T1, 15/3 for T2 and 10/3 for T3. In assays T1 and T2 juvenile prawns and fish were used, while in T3 post-larvae prawns and pre-juvenile fish were used. To test the survival with or without fed, it was schedule a four-day feeding ad libitum period, following by a two-day fed depravation period in all the assays.

Results: In assays with juveniles of $M$. tenellum the survival rate was superior to $80 \%$ with or without shelter, when T1 showed 97-100\% survival; meanwhile T3 presented a $56.67 \%$ of survival, suggesting it's necessary to use only juvenile prawns in co-culture systems. The use of shelters and fed deprivation had no significant effects on the survival of prawns.

Limitations on study/implications: $M$. tenellum is an important aquatic resource for the central Mexican Pacific, region in which the $D$. latifrons is a representative native fish with a developing aquaculture. A polyculture or co-culture system with these species can accelerate the sustainability of both species productions. Findings/conclusions: The results suggest this polyculture system may be feasible, and longer duration culture are recommended.
\end{abstract}

Keywords: co-culture, river shrimp, Pacific fat sleeper, shelter, feed deprivation.

\section{INTRODUCTION}

Polyculture systems are becoming more relevant among producers in global aquaculture. Polyculture requires two or more cultured species in the same physical space at the same time (Stickney, 2013), preferably with different ecological niche (Wang \& Lu, 2016). The 
importance of polyculture systems in today's aquaculture lies in is capacity to be a valuable option to increase the efficiency and the sustainability of production systems (Dumont $e t$ al., 2013), and in improving the system functionality by taking advantage of coexistence and interaction between species (Thomas et al., 2020). Other advantages of implementing a polyculture grow-out are the mitigation of environmental impact of effluents, reduction of nitrogenous waste, and provide food security for rural population (Martínez-Porchas et al., 2010).

One of the main requirements of this production systems is to utilize compatible species in environment, and that these species do not present antagonistic feeding behavior (Wang $\& \mathrm{Lu}, 2016)$. Although is very common to use two or more fishes of high economic value (Stickney, 2013), several studies report the positive results of polyculture grow-out with prawn of the Macrobrachium genus and tropical fishes (García-Pérez et al., 2000; Dos Santos \& Valenti, 2002; Tidwell et al., 2010; Cebreros et al., 2013; Henry-Silva et al., 2015).

Macrobrachium tenellum is a tropical species of prawn with gastronomic importance and great market value in Mexico, Guatemala and El Salvador, when is commonly referred as river shrimp (Vargas-Ceballos et al., 2020). This species is found in abundance in natural populations mainly near coastal areas; has a high tolerance to temperature, salinity and dissolved oxygen fluctuation and is not an aggressive species (Espinosa-Chaurand et al., 2011). Garduño-Dionate et al. (2017), mention that in its natural environment this prawn is over-fished, and commonly caught when individuals have not reach minimum size to secure the ecological renovation of their wild populations. The high adaptability and growing impact in their natural populations, give M. tenellum a high opportunity for its aquaculture development (Ponce-Palafox et al., 2006; Espinosa-Chaurand et al., 2011). Recent information about the grow-out of $M$. tenellum suggest is necessary to integrate methods and techniques used in other tropical shrimps to increase the cultivation effort of this resource (Peña-Herejón et al., 2019). In this regard, polyculture systems represent an interesting alternative to increase the production and availability of farmed shrimps in Mexico.

The Pacific fat sleeper (D. latifrons), is a native fish with an increasing importance as food resource in many coastal regions of the Pacific in countries like Mexico, Ecuador and Peru (Castro-Rivera et al., 2005; Basto-Rosales et al., 2019). Polyculture viability of D. latifrons with other fishes is currently under study, and there's still a potential for the development of sustainable farm systems with other species that could benefit from the synergistic relation with the Pacific fat sleeper.

After the evaluation of the aforementioned information, we decided to test the potential compatibility of $M$. tenellum and D. latifrons with the implementation of a co-culture system to evaluate the survival of the prawn under confinement conditions with the fish, considering the presence and absence of food and shelters. The aim is to determine if it would be efficient to consider a polyculture system with both species.

\section{MATERIALS AND METHODS}

To evaluate our proposition, we used individuals of $M$. tenellum and D. latifrons collected in El Quelele Lagoon located in Nuevo Vallarta, Nayarit, Mexico, and in El Salado estuary 
located in Puerto Vallarta, Jalisco, Mexico. The organisms were transported under constant aeration $\left(4 \mathrm{mg} \mathrm{O}_{2} \mathrm{~L}^{-1}\right)$ inside a $400 \mathrm{~L}$ water container to the facilities of the Laboratory of Water Quality and Experimental Aquaculture (LACUIC) from the Centro Universitario de la Costa (University of Guadalajara), in Puerto Vallarta, Jalisco, Mexico. Inside the laboratory the fishes underwent an ectoparasite removal treatment in a $200 \mathrm{~L}$ container with a concentration of $0.3 \mathrm{~mL}$ of Dimilin ${ }^{\circledR}$ (diflubenzuron 22\%) for 10 minutes. The fish and prawns were kept separate by species in a seven-day quarantine in $500 \mathrm{~L}$ water tanks with constant recirculation. Dissolved oxygen was monitored daily using an oximeter (YSI $\left.{ }^{\circledR} 550 \mathrm{~A}\right)$.

After expiration of the quarantine period, we design a series of three assays using different size organisms from each species. In a first assay (T1) 15 random organisms of each species were arranged in circular tanks with 1,700 L capacity and a dimension of $2.37 \mathrm{~m}^{2}$ (density: 13 individuals. ${ }^{-2}$ ), with and without shelters (eight PVC pipes in each tank), using three replicates for each treatment. Before sow, the organisms were measured in size and weight (Table 1). Then, the prawns were stocked first and later the fish. Organisms were fed ad libitum during a four-day period, following by a two-day feed deprivation period. To evaluate survival in this assay, organisms of each species were counted after the expiration of each period.

The second assay (T2) consisted in the confinement of three of the larger fish resulting after the first assay with 15 random prawns in $1,700 \mathrm{~L}$ tanks and a dimension of $2.37 \mathrm{~m}^{2}$ (density: 8 individuals.m ${ }^{-2}$ ) with or without shelter (eight PVC pipes in each tank) (Table 1). The fish were randomly located in the three replicates of each treatment. For this assay we proceed with feeding and feed deprivation periods similar to T1, after each period was over the surviving organisms were counted.

The third assay (T3) was realized in $40 \mathrm{~L}$ fish tanks, each one with 10 prawns and three fish of shorter size that the previous assays (density: 104 individuals. $^{-2}$ ) (Table 1). As in the previous assays, we tested a treatment with shelter and without shelter (four PVC pipes in each tank) with three replicates. Feeding and feed deprivation periods were the same as the previous assays, and we counted the surviving organisms by species after every period.

All trials lasted six days and the same balanced feed was used in all of them (commercial balanced feed for tilapia "Grow fish Tilapia $2^{\circledR}$ ": protein $35 \%$, moisture $12 \%$, fat $5.6 \%$, crude fiber 5\%, ash 8\% and ELN 34.5\%). During all the assays, we registered the water physicochemical parameters (temperature, dissolved oxygen and $\mathrm{pH}$ ) on a daily basis.

Table 1. Design of the assays: initial average size (mean \pm SD) and number of individuals of each species per tank (unit).

\begin{tabular}{|c|c|c|c|c|c|c|}
\hline \multirow{3}{*}{ Species } & \multicolumn{6}{|c|}{ Assays } \\
\hline & \multicolumn{2}{|c|}{ T1 } & \multicolumn{2}{|c|}{$\mathbf{T} 2$} & \multicolumn{2}{|c|}{ T3 } \\
\hline & Size $(\mathbf{c m})$ & Ind. Unit ${ }^{-1}$ & Size $(\mathbf{c m})$ & Ind. Unit ${ }^{-1}$ & Size $(\mathbf{c m})$ & Ind. Unit ${ }^{-1}$ \\
\hline Macrobrachium tenellum & $4.95 \pm 0.82$ & 15 & $4.95 \pm 0.82$ & 15 & $1.38 \pm 0.35$ & 10 \\
\hline Dormitator latifrons & $20.60 \pm 2.93$ & 15 & $26.39 \pm 1.46$ & 3 & $9.50 \pm 1.77$ & 3 \\
\hline
\end{tabular}


A statistical evaluation was performed with the Friedman's test taking average size, presence/absence of feeding and presence/absence of shelter as factors (explanatory variables), and the survival of the prawns as the response variable. The Friedman test was performed using the R-software (R Core Group, USA) with a statistical significance of $\alpha=0.05$.

\section{RESULTS AND DISGUSSION}

The results in each assay suggest that the survival rate of the prawns were not affected by the feeding or fed deprivation period, the presence/absence of shelter or the average size of sow $(\mathrm{p}<0.05)$ (Table 2). The lower survival rate of $M$. tenellum obtained in T3 may be due to depredation from the fish caused by the smaller average size of the prawns (1.38 0.35), a size that is considered in the post-larval range (Jáuregui-Velázquez \& BárcenasGutiérrez, 2017). In this regard, New \& Valenti (2017) indicate small size in prawn makes them susceptible to be eating by fishes in aquaculture systems. The prawns that not survive during $\mathrm{T} 1$ and $\mathrm{T} 2$ were found dead, dismissing the idea that they were preyed upon by fish in those assays. A better survival rate was observed in T1, suggesting that the same amount of prawns as fish not only has better biological performance but also can improve the economic revenue provided by the production system.

During our assays, many interactions between prawns and fish were observed, which may have an impact on the survival rate. In M. tenellum of large size is common to find some social hierarchies when some alpha males exercise dominion over the rest of the population, negatively affecting the growth and survival of said population (Vega-Villansante et al., 2011). This behavior observed in several species of the Macrobrachium genus (Karplus \& Sagi, 2010), can be countered with the use of shelter in growing areas (De Los SantosRomero et al., 2018). In our results, the use of shelter had no significant effect on the survival of the prawns, however, it's important to consider the use of shelter to prevent events of mortality or growth impairment that could affect the production system.

Another interaction observed in decapod populations is the cannibalism of the soft organisms that have just been molted by the harder ones. Cannibalism is mostly observed during molting and post-molting cycles in post-larvae and/or juvenile stages (Tidwell $e t$ al., 2010). The use of different types of natural or artificial shelters has proven to be an

Table 2. Survival rate of Macrobrachium tenellum obtained after each period (feeding and fed deprivation) in assays with Dormitator latifrons (mean percentage $\pm \mathrm{SD}$ ).

\begin{tabular}{|c|c|c|c|}
\hline & Experimental unit & Fed ad libitum & Fed deprivation \\
\hline \multirow{2}{*}{$\mathrm{T} 1$} & With shelter & $97.78 \pm 3.85$ & $97.78 \pm 3.85$ \\
\hline & Without shelter & $100 \pm 0.00$ & $100 \pm 0.00$ \\
\hline \multirow{2}{*}{$\mathrm{T} 2$} & With shelter & $91.11 \pm 10.18$ & $92.44 \pm 0.84$ \\
\hline & Without shelter & $86.66 \pm 11.55$ & $86.15 \pm 13.64$ \\
\hline \multirow{2}{*}{$\mathrm{T} 3$} & With shelter & $56.67 \pm 45.09$ & $100 \pm 0.00$ \\
\hline & Without shelter & $56.67 \pm 41.63$ & $100 \pm 0.00$ \\
\hline
\end{tabular}

The survival rate of fed deprivation period was calculated using only the survival individuals counted after the previous period. Friedman's test did not show statistical differences. 
effective countermeasure for cannibalistic or other antagonist behaviors during shrimp pre-juvenile production (Karplus \& Sagi, 2010). In T3 we observed a significantly lesser survival rate in the prawns; as mentioned before, this was probably caused by depredation from the fish, but it's important to not discard cannibalism. Even after not finding statistical differences in the survival for the use of shelter, the state of the art about this topic suggest it's extremely important to provide shelter when shrimps are about the average size of T3 (Ponce-Palafox et al., 2006; Espinosa-Chaurand et al., 2011; Vargas-Ceballos et al., 2020).

This study is the first report of polyculture of M. tenellum with the native fish $D$. latifrons, and assays with other fishes are scarce. Vega-Villasante et al. (2011), tested the survival of M. tenellum juvenile in polyculture with different species and strains of tilapia, obtaining good survival rate for the juvenile in systems with Nile tilapia Oreochromis niloticus and Mozambique tilapia 0 . mossambicus (no evidence of predation by the fish), similar to our results in assays using juvenile prawns (T1, T2). However, when using more actives and growth-efficient tilapias like blue tilapia $O$. aureus and Thai-Chitralada O. niloticus strain (Curzon et al., 2019), the mortality of M. tenellum was almost total (Vega-Villasante et al., 2011); in this regard, observations during our assays suggest D. latifrons does not show antagonistic behavior when the prawns are of juvenile size (Table 2). The omnivorous nature of $D$. latifrons, and low antagonistic behavior observed toward juvenile shrimps, suggest it's a great fish option for the development of co-culture, biculture or polyculture systems with M. tenellum.

Other species of Macrobrachium are most commonly used in polyculture systems with fishes like tilapia or carp (New \& Valenti, 2017), comparing the survival obtained during our research with the performance of $M$. rosenbergii in different polyculture systems, we found mixed results. Dos Santos \& Valenti (2002) reported an average survival rate of $90 \%$ of $M$. rosenbergii cultivated with $O$. niloticus at different densities, and the prawn did not negatively affect the fish growth; when comparing that survival rate with the one observed during this study for T1, T2 and T3, the performance for M. tenellum was very similar. The similarities between survival rate of both systems may suggest that the interaction between the species can contribute to more sustainable production and more environmental friendly, also supported by the fact that in our study the survival was not affected by the fed deprivation period, suggesting that the prawn fed upon the not consumed fed and the feces of the fish. The survival of M. tenellum juveniles obtained in this study was similar to the survival of $M$. rosenbergii reported by Tidwell et al. (2010), who obtained between 87.5-96.3\% with tilapia cultivated in floating cages; and higher to the survival reported by García-Pérez et al. (2000), who obtained 36-43\% of survival for M. rosenbergii with tilapia, they also mentioned that high mortality of the shrimp may be related to the cannibalistic behavior observed during the grow-out and to predation by birds unrelated to the cultivation.

The survival of $M$. tenellum in our assays was more than adequate comparing with other two species of prawns. It was higher than M. amazonicum in a multi-trophic culture with tilapia, when the survival of the prawns fluctuated between 61.5-77.3\%, without affecting the tilapia production (Henry-Silva et al., 2015). Meanwhile, compared with M. americanum in ponds with tilapia, the prawn showed survival rate very similar to the obtained in our experiment, with low performance of post-larvae $(43 \%)$, and better for 
juveniles with 86\% (Cebreros et al., 2013). It's important to mention that our assays lasted less than the experiments used for comparison, however, only during our assays it was used a fed deprivation period.

Taking into account that in semi-intensive ponds, the survival of prawns and shrimps varies between $50-80 \%$, after six to eight months, and that during storage and harvest of shrimps a minimum of $50 \%$ of survival is required to become feasible (Valenti et al., 2010); the results obtained in our preliminary assays are acceptable and within the expected survival range. It's pertinent to realize trials or assays with both species, at higher densities, and with longer duration.

\section{CONGLUSIONS}

All these preliminary assays are the first report of survival evaluation of $M$. tenellum in confinement conditions with $D$. latifrons. The results obtained suggest a co-culture or polyculture system with both native species can be feasible using juveniles of $M$. tenellum and fish larger than $9.50 \pm 1.77 \mathrm{~cm}$ because predation risk is significantly lower. We do not found statistical differences between providing shelter or not, but to prevent antagonistic behavior between the species, or alpha male effect and interspecies cannibalism in the prawns during longer confinement, it is recommended the use of shelters in the tanks. Continuing research about this polyculture system will have an important impact on fisheries and aquaculture in central Mexican Pacific region, preventing exotic species introduction like tilapia may diminish the wild populations of both species and providing food security for the region with a more diverse protein source availability.

\section{AGKNOWLEDGEMENTS}

Gabriela E. Musin thanks the Government of Mexico, through the Ministry of Foreign Relations, for the scholarship awarded. Daniel Badillo-Zapata want to thanks CONACyT and the Cátedras project of CONACyT for the support provided for carrying out this study. David J. Palma-Cancino thanks the CONACyT for the grant No. 769329 provided for his postdoctoral research.

\section{REFERENGES}

Asiain-Hoyos, A., Reta-Mendiola, J.L., García-Sánchez, A.I., \& Domínguez-Mora, J. (2020). The tilapiaprawn polyculture: its development in Mexico. Agro Productividad, 13(11): 31-36. Doi: 10.32854/agrop. v13il1.1808

Badillo-Zapata, D., Zaragoza, F.D.J., Vega-Villasante, F., López-Huerta, J.M., Herrera-Reséndiz, S., CuetoCortés, L., \& Guerrero-Galván, S.R. (2018). Requerimiento de proteína y lípidos para el crecimiento de juveniles del pez nativo Dormitator latifrons (Richardson, 1844). Ecosistemas y Recursos Agropecuarios, 5(14): 345-351. Doi: 10.19136/era.a5n14.1554

Basto-Rosales, M.E.R., Rodríguez-Montes de Oca, G.A., Carrillo-Farnés, O., Álvarez-González, C.A., Badillo-Zapata, D., \& Vega-Villasante, F. (2019). Growth of Dormitator latifrons under different densities in concrete tanks. Tropical and Subtropical Agroecosystems 22: 489-493.

Castro-Rivera, R., Aguilar-Benítez, G., \& Hernández-Girón, J.P. (2005). Conversión alimenticia en engordas puras y mixtas de Popoyote (Dormitator latifrons Richardson) en estanques de cemento. Revista AquaTIC, 23: 45-52.

Cebreros, A.R., García-Guerrero, M., Molina, P.A., \& Miranda, A.S. (2013). A preliminary assay on the mixed culture of red Florida tilapia and freshwater prawn Macrobrachium americanum stocked in outdoor tanks at different tilapia densities. Agricultural Sciences, 4(7): 345-352. 
Curzon, A.Y., Shirak, A., Dor, L., Zak, T., Benet-Perelberg, A., Seroussi, E., \& Ron, M. (2019). Hybrid origin of the Thai-Chitralada tilapia strain using DNA barcoding and microsatellite analysis. The Israeli Journal of Aquaculture - Bamidgeh, 71: 1-7. Doi: 10.46989/001c.20988

De los Santos-Romero, R.B., García-Guerrero, M.U., Alpuche-Osorno, J.J., \& Cortes-Jacinto, E. (2018). The effect of alpha males and shelter type on growth and survival of the longarm prawn Macrobrachium tenellum (Smith, 1871). Latin American Journal of Aquatic Research, 46(3): 551-557. Doi: 10.3856/vol46issue3-fulltext-8

Dos Santos, M.J.M., \& Valenti, W.C. (2002). Production of Nile tilapia Oreochromis niloticus and freshwater prawn Macrobrachium rosenbergii stocked at different densities in polyculture systems in Brazil. Journal of the World Aquaculture Society, 33(3): 369-376. Doi: 10.1111/j.1749-7345.2002.tb00513.x

Dumont, B., Fortun-Lamothe, L., Jouven, M., Thomas, M., \& Tichit, M. (2013). Prospects from agroecology and industrial ecology for animal production in the 21th century. Animal, 7(2013): 1028-1043.

Espinosa-Chaurand, L.D., Vargas-Ceballos, M.A., Guzmán-Arroyo, M., Nolasco-Soria, H., Carrillo-Farnés, O., Chong-Carrillo, O., \& Vega-Villasante, F. (2011). Biología y cultivo de Macrobrachium tenellum: estado del arte. Hidrobiológica, 21(2): 99-117.

García-Pérez, A., Alston, D.E., \& Cortés-Maldonado, R. (2000). Growth, survival, yield, and size distributions of freshwater prawn Macrobrachium rosenbergii and Tilapia Oreochromis niloticus in polyculture and monoculture systems in Puerto Rico. Journal of the World Aquaculture Society, 31(3): 446-451. Doi: 10.1111/j.1749-7345.2000.tb00894.x

Garduño-Dionate, M., Pérez-Velázquez, P.A., Lorán-Núñez, R.M., \& Martínez-Isunza, F.R. (2017). Crecimiento y mortalidad del langostino moya Macrobrachium tenellum (Decápoda: Palaemonidae) en el río San Pedro Mezquital, Nayarit, México. Hidrobiológica, 27(3): 359-367.

Henry-Silva, G.G., Maia, C.S.P., Moura, R.S.T., Bessa Junior, A.P., \& Valenti, W.G. (2015). Integrated multi-trophic culture of Nile tilapia (Oreochromis niloticus) and Amazon river prawn (Macrobrachium amazonicum) in brackish water. Arquivo Brasileiro de Medicina Veterinária e Zootecnia, 67(1): 265-273. Doi: $10.1590 / 1678-6788$

Jáuregui-Velázquez, E.E., \& Bárcenas-Gutiérrez, S.Q. (2017). Estructura de tallas de Macrobrachium tenellum (Decapoda: Palaemonidae) en el estero El Salado, Puerto Vallarta, Jalisco, México. Biología, Ciencia y Tecnología, 10(37): 656-671.

Karplus, I., \& Sagi, A. (2010). The biology and management of size variation. In: New, M.B., Valenti, W.C., Tidwell, J.H., D’Abramo, L.R. \& Kutty, M.N. (Eds.) Freshwater prawns: biology and farming. New Jersey: Wiley-Blackwell, pp. 316-345.

Martínez-Porchas, M., Martínez-Córdova, L.R., Porchas-Cornejo, M.A., \& López-Elías, J.A. (2010). Shrimp polyculture: a potentially profitable, sustainable, but uncommon aquacultural practice. Revieres in Aquaculture, 2: 73-85. Doi: 10.1111/j.1753-5131.2010.01023.x

New, M.B., \& Valenti, W.C. (2017). Tilapia-Macrobrachium polyculture. In: Perschbacher, P.W. \& Stickney, R.R. (Eds.) Tilapia in intensive co-culture. New Jersey: Wiley-Blackwell, pp. 156-185.

Peña-Herrejón, G.A., Sánchez-Velázquez, J., García-Trejo, J.F., Soto-Zarazúa, G.M., \& Rico-García, E. (2019). Effect of stocking density on growth and survival of the prawn Macrobrachium tenellum, cultured in a recirculating aquaculture system. Latin American Journal of Aquatic Research, 47(2): 342-348. Doi: 10.3856/vol47-issue2-fulltext-14

Ponce-Palafox, J.T., García Ulloa, M.G., Arredondo Figueroa, J.L., Hernández Ocampo, D., Díaz Alvarez, J., Aldama Rojas, G., \& Esparza Leal, H. (2006). El cultivo del camarón de agua dulce Macrobrachium tenellum en estanques rústicos. IV Congreso Iberoamericano Virtual de Acuicultura (CIVA): 655-660.

Stickney, R.R. (2013). Polyculture in aquaculture. In: Christou, P., Savin, R., Costa-Pierce, B.A., Misztal, I. \& Whitelaw, C.B.A (Eds.). Sustainable food production. New York: Springer, pp. 1366-1368.

Tidwell, J.H., Coyle, S.D., \& Bright, L.A. (2010). Polyculture of Nile tilapia, Oreochromis niloticus, either confined in cages or unconfined in freshwater prawn, Macrobrachium rosenbergii, ponds. Journal of the World Aquaculture Society, 41(4): 616-625. Doi: 10.1111/j.1749-7345.2010.00402.x

Thomas, M., Lecocq, T., Abregal, G., Nahon, S., Aubin, J., Jaeger, C., Wilfart, A., Schaeffer, L., Ledoré, Y., Puillet, L., \& Pasquet, A. (2020). The effects of polyculture on behaviour and production of pikeperch in recirculation systems. Aquaculture Reports, 17(2020): 100333. Doi: 10.1016/j. aqrep.2020.100333

Valenti, W.C., New, M.B., Salin, K.R. \& Ye, J. 2010. Grow-out systems: monoculture. In: New, M.B., Valenti, W.G., Tidwell, J.H., D’Abramo, L.R. \& Kutty, M.N. (Eds.) Freshwater prawns: biology and farming. New Jersey: Wiley-Blackwell, pp. 154-179. 
Vargas-Ceballos, M.A., Badillo-Zapata, D., Chong-Carrillo, O., Ponce-Palafox, J.T., Hernández-Hernández, L.H., \& Vega-Villasante, F. (2020). Intake of different food sources in the first zoeae stages of Macrobrachium tenellum (Decapoda: Palaemonidae). Latin American Journal of Aquatic Research, 48(1): 156-161. Doi: 10.3856/vol48-issuel-fulltext-2344

Vega-Villasante, F., Martínez-López, E.A., Espinosa-Chaurand, L.D., Cortés-Lara, M.C., \& Nolasco Soria, H. (2011). Crecimiento y supervivencia del langostino (Macrobrachium tenellum) en cultivos experimentales de verano y otoño en la costa tropical del Pacífico mexicano. Tropical and Subtropical Agroecosystems, 14(2): 581-588.

Wang, M., \& Lu, M. (2016). Tilapia polyculture: a global review. Aquaculture Research, 47: 2363-2374. Doi: $10.1111 /$ are. 12708 